\title{
Religie en politieke rituelen en symbolen in Nederland na 18131
}

\author{
ANDRE I. WIERDSMA
}

\section{INLEIDING}

Na de Franse overheersing werd Nederland met de grondwet van 1814 hersteld als een zelfstandige natie-staat. Een jaar later volgde op de besluiten van het Congres van Wenen, de 'Wet van Europa', de vereniging met België tot het Verenigd Koninkrijk onder koning Willem I. Ook de grondwetswijziging van 1815 legde het accent op de centrale organisatie van de eenheidsstaat die aan het eind van de achttiende eeuw werd gevestigd, maar daarmee nog geen nationale zaak was geworden. In het vergelijkend onderzoek naar processen van staats- en natie-vorming wordt dan ook behalve op de staatsrechtelijke structuur gelet op de officiële ceremonieën en symbolen die bijdragen aan de algemene identificatie met het politieke centrum ${ }^{2}$. In Nederland hebben voornamelijk juristen aandacht besteed aan dergelijke gebruiken. Het meest bekend is waarschijnlijk de beschrijving van E. van Raalte van de opening der Staten-Generaal en zijn verzameling van de troon- en inhuldigingsredes vanaf het begin van de negentiende eeuw tot 1964 3. Sindsdien hebben anderen zich kritischer uitgelaten met'name over de religieuze aspecten: het koningschap 'bij de gratie Gods', de bede in de troonrede, de Koninklijke Boodschap bij nieuwe wetsontwerpen eindigend met het 'in Godes heilige bescherming' bevelen van de Kamer en dergelijke 'antiquiteiten'. Nederland is volgens dit forum niet langer een christelijke natie ${ }^{4}$. De kritiek veronderstelt dat voorheen het staatsceremonieel niets anders was dan de uitdrukking van gemeenschappelijke cultuurelementen. Dat komt overeen met de gangbare sociologische/cultureel antropologische definitie van het collectieve ritueel: een plechtige, van het alledaagse onderscheiden reeks van handelingen, waarin op directe of meer symbolische wijze de algemene waarden, nonnen en doeleinden van de gemeenschap worden bevestigd ${ }^{5}$.

1 Deze tekst is een bewerking van een paper voor de 'International Conference for the Sociology of Religion', 19-23 augustus 1985 te Leuven. Het onderzoek werd gesteund door de Stichting voor theologisch en godsdienstwetenschappelijk onderzoek in Nederland, die wordt gesubsidieerd door de Nederlandse organisatie voor zuiver-wetenschappelijk onderzoek (ZWO).

2 Zie S. Rokkan, 'Nation-Building: A Review of Models and Approaches', Current Sociology, XIX (1971) iii, 7-38.

3 E. van Raalte, De geschiedenis van de opening der Staten-Generaal van 1814-1952 ('sGravenhage, 1952) en idem. Troonredes, openingsredes en inhuldigingsredes 1814-1963 ('sGravenhage, 1964).

4 Zie F. van Vugt, 'Non orare, sed laborare, of: het Godsbesef in staatsrechtelijk verband', Ars Aequi, XXX (1981) 319-327; A. P. Funke, 'God en de Tweede Kamer', Nederlands Juristenblad (1974) 1195-1198; D. J. Veegens, 'Bij de gratie Gods', Ibidem (1977) 233-236 en H. van den Brink, 'Bij de gratie Gods', Tijdschrift voor overheidsadministratie (1980) 547-549.

s Zie J. A. A. van Doorn en C. J. Lammers, Moderne Sociologie (Utrecht, 1976) 300-301. Voor een uitvoeriger overzicht: J. R. Gusfield en J. Michalowicz, 'Secular Symbolism', Annual Review of Sociology, X (1984) 417-437. 
Een dergelijke interpretatie van de betekenis van rituelen en symbolen voor de moderne samenleving heeft in Engeland en in de Verenigde Staten schooi gemaakt. De Amerikaanse godsdienstsocioloog R. N. Bellah vatte de algemene godsdienstigheid, die in het staatsceremonieel zou worden vertolkt, samen in het van J.-J. Rousseau overgenomen begrip 'civil religion', een publieke godsdienst 6. Maar het ontstaan van het Nederlandse staatsceremonieel in het begin van de negentiende eeuw laat zien dat politieke rituelen en symbolen in tijden van crisis niet zozeer uitdrukking geven aan de nationale saamhorigheid, maar instrumenten zijn in het proces van natie-vorming. In de strijd tegen Napoleon na 1813 werden verschillende plechtigheden in het vage grensgebied van godsdienst en politiek ingesteld om na de vereniging van Nederland en België in 1815 sterk te worden gewijzigd. Daarna werden de religieuze kenmerken van het staatsceremonieel betrokken in de conflicten rond de scheiding van kerk en staat en de verdere secularisering in de negentiende en twintigste eeuw.

\section{DE TWEE TRADITIES VAN HET NEDERLANDSE NATIE-BESEF}

Eind zestiende en begin zeventiende eeuw was de Opstand tegen Spanje de motor van een politiek unificatie-proces waaruit althans in de bovenlagen van de bevolking, de kooplieden en predikanten, een zekere nationale identiteit zou voortkomen. Naast en soms tegenover elkaar ontstonden twee tradities: de in godsdienstige zaken tolerante Hollandse koopmanstrots en de calvinistische of hervormde traditie ${ }^{7}$. In de strijd tegen Napoleon, aanvankelijk meer een strijd met woorden dan met wapens, werden beide tradities aangesproken.

In november 1813 leek Napoleon al verslagen. De zee was open, de koophandel zou herleven: 'De oude tijden komen wederom', aldus de eerste proclamatie van het nieuwe Algemeen Bestuur onder leiding van G. K. van Hogendorp. In de jaren daarvoor was het nationaal besef van de oud-regent gegroeid tot een alle partijen, standen, en gezindten omvattende eenheidsgedachte. Kenmerkend waren de veranderingen in de visie van Van Hogendorp op de relatie tussen kerk en staat. In 1787 verscheen een brochure van zijn hand over de 'Noodzakelijkheid eener Heerschende religie in den Staat'. Enkele jaren later zou Van Hogendorp deze verhandeling 'gaarne uit de wereld hebben gehad' en werd meer op historische gronden de bijzondere positie van de hervormde kerk verdedigd tegenover de in 1796 door de Bataafse

6 R. N. Bellah, 'Civil Religion in America', in: idem. Beyond Belief (New York, 1970) 168189. Een uitgebreid literatuuroverzicht geeft G. Gehrig, American Civil Religion: An Assessment (Society for the Scientific Study of Religion, Monograph series, 3, 1981).

7 J. Goudsblom, 'De Nederlandse samenleving in ontwikkelingsperspectief, Symposion, I (1979) 12. De Hollandse traditie werd uiteengezet door J. C. Boogman, 'Enkele aspecten van het Nederlandse natie-besef in historisch perspectief, Oost-West (Civis Mundi), V (1966) 75-80, en de hervormde of calvinistische traditie onder anderen door G. Groenhuis, 'Calvinism and National Consciousness: the Dutch Republic as the New Israel', in: A. C. Duke en C. A. Tamse, ed., Britain and the Netherlands, VII ('s-Gravenhage, 1981) 118-133. 
revolutionairen uitgevaardigde scheiding van kerk en staat. In 1802 herhaalde hij nog eens de oproep tot het herstel van de publieke kerk. Zij had getoond buiten de staat te kunnen, maar de staat zou niet zonder de kerk 'den vereischten eerbied van het volk voor de regering' kunnen bewaren. Bij het herstel van de bevoorrechte kerk diende echter een zo groot mogelijke verdraagzaamheid in acht te worden genomen: ook andersdenkenden zouden ondergeschikte ambten kunnen vervullen. Maar de bekende Schets van Van Hogendorp, het grondwetsontwerp voor de Verenigde Nederlanden tijdens de Franse overheersing opgesteld, brak met het beginsel van een heersende kerk $^{8}$.

Nog in 1811 had Van Hogendorp geen vertrouwen in de gedachte dat het volk de teugels in eigen handen zou moeten nemen om aan te sturen op herwinning van de nationale onafhankelijkheid. De verbreiding van godsdienstige beginselen zou voldoende zijn om het kwaad te overwinnen. 'Dieu fera le reste'. Onder invloed van de Spaanse en Duitse opstand tegen de Napoleontische overheersing groeide echter de overtuiging dat de nieuwe staat door een 'public spirit' zou moeten worden gedragen 9. In dit perspectief paste het oude godsvertrouwen niet meer. De proclamatie bij de vestiging van het provisionele bestuur, 20 november 1813, besloot dan ook met het meer vrijzinnige 'God helpt die genen, die zich zelve helpen'.

$\mathrm{Na}$ de verspreiding van de eerste proclamatie, het 'Loflied van de Restauratie', schreef Van Hogendorp over het nieuwe bestuur: 'Nous appelerons dans ce gouvernement tous les partis et tous les cultes, parce que tout esprit de parti est abjuré, et parce que les citoyens de tous les cultes appellent le même Souverain' ${ }^{10}$. Nationale onafhankelijkheid onder Oranje, burgerlijke vrijheid, en geen onderscheid naar partijschap of geloofsbelijdenis was 'de Geest der Natie' zoals Van Hogendorp die zag. Het toverwoord was 'eensgezindheid'. Deze houding was volgens Van Hogendorp onder de aanzienlijken algemeen, maar de 'grondslag van alles' en een 'zeker middel van nieuwe welvaart' zou zijn 'de bevordering van de Eensgezindheid onder de Ingezetenen' 11.

Terwijl het Verlichtingsdenken de nadruk legde op non-dogmatisme en tolerantie, kortom een 'algemeen christendom' tegenover de vroegere orthodoxe leer werd gesteld ${ }^{12}$, werden in de strijd tegen de Fransen vanaf eind 1813 de vertrouwde beelden van de oude calvinistische traditie onder het volk verspreid. In de vele

8 Geciteerd in: B. de Gaay Fortman, Gijsbert Karel van Hogendorp en de grondwet van 1814 (Amsterdam, 1907) 27-28, 39 noot 1.

9 J. Haak, 'Het nationaal besef bij G. K. van Hogendorp', Tijdschrift voor Geschiedenis, LXXIX (1966) 407-417. De eenheidsgedachte bij Van Hogendorp lijkt sterker dan Haak laat uitkomen. Van Hogendorp gebruikte de uitdrukking 'public spirit' in zijn Aanmerkingen bij de Schets eener Grondwet voor de Verenigde Nederlanden, bijlage bij het Soeverein Besluit van 21 december 1813 ter instelling van de grondwetscommissie, Staatsblad, 1813.

10 H. T. Colenbrander, Ontstaan der grondwet ('s-Gravenhage, 1909) I, 15.

11 Vergelijk Haak, 'Nationaal besef, 416 en G. K. van Hogendorp, Brieven en gedenkschriften van Gijsbert Karel van Hogendorp ('s-Gravenhage, 1866-1903) IV, 251-254.

12 L. W. G. Scholten, 'De maatschappelijke en politieke achtergronden van de grondwetsherziening van 1848', in: J. Valkhoff, ed., Grondwet en maatschappij in Nederland 1848-1948 ('s-Gravenhage, 1948) 26-27. 
pamfletten naar aanleiding van het herstel van de nationale onafhankelijkheid werden de gebeurtenissen en de belangrijkste personen aan de hand van het Oude Testament uitgetekend. Het 'Israël-model' 13 gaf zoals in de tijd van de oude Republiek rond 1813 opnieuw betekenis aan het verleden, heden, en de toekomst van de Nederlandse natie.

In de gelukkige omwenteling van 1813 was 'andermaal zichtbaar de God van Nederland', aldus de titel van een van de gelegenheidsgedichten. God bleeft trouw aan het verbond met Nederland en Oranje zoals aan het verbond met het volk van Israël: 'Gij faalt in Uw' belofte niet, al treurt de ware Sion niet'. De verlossing van Nederland was het werk van God.

Zoo bleek Gods vinger in 't verlossen uit de ellenden,

Zoo zag men in den druk, zijn vaderlijke hand,

Zoo wou de Hemel zelf ons zijnen bijstand zenden.

Zoo toonde hij zich weer den God van Nederland.

Het drievoudig snoer van God, Nederland en Oranje bracht voor het volk ook verplichtingen met zich mee. Een nieuwe Gouden Eeuw kondigde zich aan, maar 'zoo die welvaart ons nog verder mögt verbast'ren', wanneer het volk 'Uw naam en zuiv'ren dienst onteeren bleef en last'ren, Schenk ons veel liever dan, ô God! die welvaart niet'! De Oranjes zouden echter de natie in het goede spoor houden. De oudste zoon van de Prins zou een Jonathan zijn 'voor ons in 't strijden' en de gemalin van de 'Salomo van het Noorden' werd als een 'moeder Israels, een Debora geacht'. De vorst werd Salomo's wijsheid, Davids moed, en de zachtmoedigheid van Job toegedicht 14. En zoals tijdens de Opstand Spanje en de rooms-katholieken werden afgeschilderd als Babel, gebroed van Kaïn en zaad van Judas 15, zo moesten in 1813 de Fransen het ontgelden. Een lierzang getiteld 'Afscheid aan de Fransen' opende met de woorden: 'Landverwoesters! Bloedafzuigers! Rooversrot! Bondgenoten van den Satan! die met deugd en Menschheid spot'. Daartegenover stond de Prins van Oranje als symbool van vrijheid en onafhankelijkheid: 'Landhersteller! Lustaankweker! Rijk geschenk van Neêrlandsch God' ${ }^{16}$.

\section{ENKELE VROEGE PROCLAMATIES}

In de eerste maanden na het herstel van de soevereiniteit nam het nieuwe bewind

13 Zie C. Huisman, Neerlands Israël (Dordrecht, 1983).

14 Citaten uit twee pamfletten van de verzameling van de Koninklijke Bibliotheek; zie W. P.

C. Knuttel-Catalogus no. 23571 en 23586. De analogie 'Salomo van het Noorden' werd gebruikt in een kritiek van de Noord-Brabander, 24 maart 1840, op de stemmingmakerij tegen het voorgenomen huwelijk van Willem I met de katholieke hofdame van Belgisch origine Henriette d'Oultremont de Wégimont.

15 Zie L. Laeyendecker, 'Publieke godsdienst in Nederland', Sociologische Gids, XXIX (1982) 355-356.

16 Geciteerd in: D. H. Couvée en G. Pikkemaat, 1813-1815, Ons koninkrijk geboren (Alphen aan den Rijn, 1963) 78-79. 
enkele calvinistische spreekwijzen over. In de correspondentie, privé en bestuurlijk, speelde dit idioom geen enkele rol, maar klaarblijkelijk werd toch het draagvlak van de Verlichtingsideeën onvoldoende geacht. Op 21 november 1813 werd bij proclamatie de instelling van het nieuwe Algemeen Bestuur afgekondigd. Van Hogendorp en de zijnen namen de bestuurlijke taak op zich 'met vertrouwen op de hulp der Goddelijke Voorzienigheid, wier hand de aanstaande verlossing van ons verguisde Vaderland zoo zichtbaar bestuurt'. Maar ook met vertrouwen op de strijdbaarheid van het Nederlandse volk. 'Wij zullen zorgen, dat het onze Strijderen aan niets ontbreeke; dat hun vertrouwen niet wankele: de GOD van Nederland strijdt voor Ons'! De verdrijving van de Fransen werd een heilige strijd genoemd. 'Deze zaak is wettig, is heilig', schreef A. Kikkert, vice-admiraal en commandant van de marine, in een proclamatie bij de aanvaarding van de post van opper-commandant der defensie van de Maas. 'De zaak van het vaderland is de zaak van God'. Ook de Prins van Oranje liet zich niet onbetuigd. $\mathrm{Na}$ eerst in Amsterdam en daarna in Den Haag tot soevereine vorst der Verenigde Nederlanden te zijn uitgeroepen, nam hij op 6 december het bewind over van het Algemeen Bestuur. Diezelfde dag riep de vorst het volk op tot vrijwillige bewapening; een deel van de Franse legers was immers nog in het land en Napoleon was nog niet definitief verslagen. De Nederlanders werden te wapen geroepen niét, zoals tijdens de Franse overheersing, om

voor een vreemde dwingeland te strijden, die $\mathrm{u}$ hier van gebrek liet omkomen, maar om aan u de zekerheid van een gerust bestaan te bezorgen, waarin het Vaderland voorzien zal. De God van Nederland strijdt met ons; wie uwer kan aan de overwinning twijfelen ${ }^{17}$ ?

De proclamaties werden overal aangeplakt en, volgens het Soeverein Besluit, 'van de Predikstoelen der Kerken van alle Godsdienstige Gezindheden' afgelezen. De woorden van Willem I werden in de plaatselijke nieuwsbladen gepubliceerd en de leuze 'de God van Nederland strijdt met ons' werd door de lokale overheden herhaald 18. Uitgerekend op deze belangrijke momenten - een nieuw Algemeen Bestuur en de oproep tot wapening - bevestigde de politieke elite het oude protestantse natiebesef.

\section{RITUELEN EN SYMBOLEN VAN DE PROTESTANTSE NATIE}

De grondwet van 1814 en het aanstellen van de benodigde ambtenaren ondersteunden de nieuwe politieke orde. Het was tijd, schreef Van Hogendorp in een terugblik op deze periode, 'om de revolutionaire tint van de Regering weg te nemen'19. Maar even zo goed werden oude gebruiken hersteld en nieuwe plechtigheden ingesteld. Zo

17 De geciteerde proclamaties zijn opgenomen in het Staatsblad, respectievelijk 21 november, 26 november en 6 december 1814.

18 Zie bijvoorbeeld de Staatscourant van 1 maart en 27 mei 1814.

19 Van Hogendorp, Brieven, VI, 93. 
werd de godsdienstzin van het nieuwe bewind keer op keer publiekelijk bevestigd met het oog vooral op het protestantse volksdeel. En met enig succes. De reacties op de oproep tot wapening van de vorst laten iets zien van de vrijheidseuforie. Wekenlang meldden de Staatscourant en lokale nieuwsbladen allerlei schenkingen en op betrekkelijk korte termijn kon een leger van ongeveer 25.000 man onder de wapenen worden gebracht. Evenals in de zeventiende en achttiende eeuw vond men steun in de 'traditional covenant with God and freedom' zoals de Engelse historicus S. Schama de oude dominante ideologie kort heeft samengevat ${ }^{20}$.

In de soevereiniteit 'bij de gratie Gods', de godsdienst van het staatshoofd vastgelegd in de grondwet, het ceremonieel van de beëdiging en inhuldiging, de door de staat uitgeschreven bede-dagen, de regeling van de zondagsrust, en het ambtsgebed of publieke gebed werd het godsdienstige en specifiek protestantse karakter van de Nederlandse natie tot uitdrukking gebracht.

\section{Soevereiniteit 'bij de gratie Gods'}

Bij de aanvaarding van de soevereiniteit op 2 december 1813, stelde Willem I een grondwet in het vooruitzicht. Nog vóór de jaarwisseling werd een commissie ingesteld die tot taak had een grondwetsontwerp te formuleren dat zowel de toets van de soevereine vorst als 'de beoordeling van notabelen uit de gehele natie' zou kunnen doorstaan. De Schets van Van Hogendorp was het uitgangspunt van de grondwetscommissie van 1814. Voor de eerste vergadering werd door Van Hogendorp, die als voorzitter optrad, een stuk bijgevoegd met het opschrift ' Algemeene Gronden van de Constitutie'. Per hoofdstuk werden in het kort de uitgangspunten van het ontwerp weergegeven. Daaraan vooraf gingen enkele meer algemene opmerkingen zoals de gedachte dat de vorst eerst de eed op de fundamentele wetten zou afleggen om daarna de huldiging van de Staten-Generaal en later - schriftelijk - van de Provinciale Staten in ontvangst te nemen. Dat was geen toevallige opmerking over het protocol, maar de symbolisering van een staatsrechtelijke opvatting die zich onderscheidde van de elders in Europa op het 'droit divin' gebaseerde restauratie. 'De Souvereiniteit uit den boezem der Staat overgebracht tot het Hoofd van den Staat was eigentlijk de karakteristieke trek van mijn Ontwerp', schreef Van Hogendorp in zijn gedenkschriften21.

Maar Willem I had weinig ontzag voor de fundamentele wetten. De grondwet was niet veel meer dan de rechtsgrond voor de sterk gecentraliseerde besluitenregering. Daarin was geen plaats voor Van Hogendorp en zijn consensusmodel voor het overleg tussen staatshoofd en volksvertegenwoordiging. Nadat tijdens de 'Grote Vergadering' van de notabelen eind maart 1814 de hoofdlijnen van de grondwet waren opgehelderd door C. F. van Maanen, Van Hogendorp bleef ziek in Den Haag achter, overhandigde Willem I de grondwettekst aan de voorzitter. Deze ceremonie suggereerde dat de vertegenwoordigde natie de constitutie ontving uit handen van dé 
soeverein $^{22}$. Dat was geheel in de geest van de restauratie, zoals Willem I ook met de nieuwe toevoeging 'bij de gratie Gods' in de titulatuur aansluiting zocht bij de herstelde Europese vorstenhuizen 23.

\section{De godsdienst van het staatshoofd}

De concrete bepalingen van de Schets met betrekking tot de godsdienst zouden uiteindelijk sterk worden gewijzigd. Enkele leden van de grondwetscommissie bepleitten de terugkeer van de bevoorrechte of heersende kerk en ten minste zou de godsdienst van de soevereine vorst in de grondwet moeten worden vastgelegd. Anderen misten in de Schets een positieve formulering van de gelijke rechten voor alle kerkgenootschappen. Beide wijzigingsvoorstellen werden de commissie door Van Hogendorp ontraden. Het een strookte niet met de 'Geest der Natie' zoals hij die zag. De geloofsvrijheid, ook geldend voor de leden van het Huis van Oranje die allen in de hervormde leer werden opgevoed, zou voldoende zekerheid bieden voor het protestantse volksdeel. Tegen het gelijkheidsbeginsel had Van Hogendorp geen enkel bezwaar, maar hij gaf er de voorkeur aan 'dat dezelve niet openlijk uitgedrukt worde, kunnende de zaak geschieden, zonder daarvan openlijk gewag te maken'. De voorstanders van de staatskerkgedachte moesten worden ontzien en het stilzwijgen van de grondwet op dit punt was voor anderen, de oud-revolutionairen en katholieken, een 'genoegzaam bewijs dat men niemand van de genoemde rechten heeft willen uitsluiten'.

Nadat de stemmen staakten, werd besloten beide voorstellen, door Van Hogendorp samengevoegd: het aannemen van het eerste amendement maakte het tweede noodzakelijk, aan de soevereine vorst voor te leggen. Deze verklaarde 'na rijpe overweging der zaak ... dat die beide pointen in de Grondwet zouden gebracht worden'. De vorst had toegegeven aan de overweging dat hijzelf wel geen gebruik zou maken van het recht op de godsdienstvrijheid en vele notabelen in het weglaten van het artikel betreffende de godsdienst van het staatshoofd reden zouden zien de gehele grondwet te verwerpen ${ }^{24}$.

\section{Beёdiging en inhuldiging}

Al op 19 december 1813 ontving Van Hogendorp een schrijven van Willem I waarin op- en aanmerkingen betreffende de Schets als ook enkele overdenkingen en vragen over de verdere gang van zaken ter sprake werden gebracht. In grote lijnen werd hetgeen de vorst toen voor ogen stond ook ten uitvoer gebracht. Alleen het tijdschema, in januari de keuze van de notabelen en vervolgens in februari de 'Constitutie aan den gang brengen', werd niet gehaald. Bij Soeverein Besluit werd

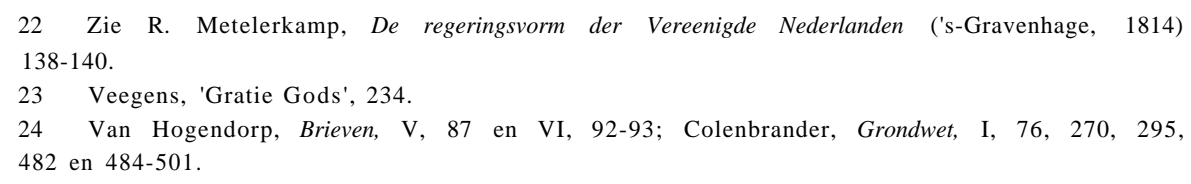


op 2 februari 1814 een commissie ingesteld met de opdracht alle benodigde maatregelen te treffen voor de bijeenkomst der notabelen ter beoordeling van het grondwetsontwerp en voor de 'eventuele' inhuldiging van de soevereine vorst. De commissie kreeg verschillende richtlijnen mee. Het aantal op te roepen notabelen zou waarschijnlijk worden bepaald op zeshonderd. De vorst wenste de vergadering der aanzienlijken te openen en daar de eed op de grondwet 'aan de vertegenwoordigers der natie te doen'. De beraadslagingen zouden plaatsvinden in de grote zaal van het paleis in Amsterdam en de inhuldiging diende te worden gevolgd door-een godsdienstige plechtigheid in de Nieuwe Kerk. Amsterdam was als republikeins bolwerk de aangewezen plaats voor het inhuldigingsceremonieel. De vergadering van de notabelen werd echter niet in het paleis belegd. Tijdens de beraadslagingen over het conceptreglement tot invoering van de grondwet werd namelijk geopperd het getal der notabelen te verdubbelen 'teneinde zoveel minder misnoegden te maken'. De verdubbeling vond uiteindelijk geen doorgang, maar wel het voorstel van Van Hogendorp om in dat geval de Nieuwe Kerk in Amsterdam voor de plechtigheden te bestemmen ${ }^{25}$. Uit praktische overwegingen werd dus de Nieuwe Kerk het decor van de inhuldigingsplechtigheid, maar dat doet aan de symbolische betekenis niets af. Later zou het een gelukkige keuze worden genoemd: de Nieuwe Kerk was tegelijkertijd een godshuis en een pantheon, een symbool van de Nederlandse natie ${ }^{26}$.

Nadat de voorzitter van de notabelenvergadering met een korte toespraak 'op de aanneming der Grondwet toepasselijk' de inhuldigingsrede van de vorst beantwoord had, de eed door de vorst en vervolgens door de leden van de vergadering was afgelegd en de Wapenheraut driemaal luid 'Leve Willem Frederik ... ' geroepen had, werd de plechtigheid van de beëdiging en inhuldiging afgesloten met muziek. Met dit intermezzo werd de overgang naar de godsdienstige plechtigheid aangegeven. Staat en kerk waren immers formeel gescheiden.

Petrus Haack, die zich tijdens de Franse overheersing als Oranje-predikant had onderscheiden, was door de soevereine vorst opgedragen tot het houden van een godsdienstige redevoering die, 'Kerkelijk Goedgekeurd', later werd gepubliceerd. Het hoofdthema van de prediking was de 'zoo belangrijke waarheid ... dat wij de verlossing van ons dierbaar Vaderland, aan God te danken hebben, en dat daar uit onze gewigtige verpligting van zelfs voortvloeit, om dit dankbaar en eensgezind te erkennen'. Het was God die de aanwezigen 'tot blijde getuigen maakt van eene zoo plegtig beëedigde Staatsregeling' waarbij - Haack citeerde de publikatie van 2 maart ter aankondiging van de grondwetsvergadering — de 'Godsdienst als de bron van alles goeds geëerbiedigd en gehandhaafd, en het grootste en onschatbare voorregt van een vrij volk, deszelfs onafhankelijkheid bewaard wordt'. Dat besef moest geheel het volk tot een eerbiedig vertrouwen op God opwekken en diende vergezeld te gaan van het besef van de 'verpligting aan onzen Vorst en het Vaderland'. De 
soevereine vorst had van zijn kant met het uitschrijven van een algemene dank- vasten bededag en de waarborging van de vrijheid van het volk door de constitutie getoond de belangen van godsdienst en vaderland te dienen ${ }^{27}$.

\section{Algemene dank-vast-en bededagen, zondagswet, en ambtsgebed}

De instelling van de algemene dank- vast- en bededagen was in de woorden van Willem I een van de eerste stappen in'de spoedige herstelling dier vaderlandsche zeden, gebruiken en inrichtingen, die onder de oorzaken van deszelfs voormaligen bloei mede mogten gesteld worden' ${ }^{28}$. Vanaf 1713 waren deze in gebruik gekomen en tot 1795 jaarlijks door de Staten-Generaal uitgeschreven. Tijdens de Franse overheersing raakten de dank- en bededagen in het slop nadat ze onder raadpensionaris $\mathrm{R}$. J. Schimmelpenninck opnieuw waren ingesteld als concessie aan hen die meenden dat in 1795 de Republiek volledig met 'Neêrlands God' had gebroken 29. Voor het orthodox-protestantse volksdeel betekenden deze dagen een manifestatie en versterking van de eenheid van het volk door, zoals later A. Kuyper in Ons Program schreef, 'langs den weg der verootmoediging in te gaan in de gemeenschap met zijn God'. De predikanten van de achttiende eeuw zagen er een bevestiging in van de betekenis van hun ambt voor het vaderland en beoordeelden de godsdienstzin van de overheid aan de biddagbrief, het begeleidend schrijven bij de jaarlijkse bede-dag 30 .

Bij Soeverein Besluit van 26 december 1813 werd een algemene dank- vast- en bededag vastgesteld voor 13 januari ter gelegenheid van het herstel van de Nederlandse onafhankelijkheid, hetgeen zoals het in de overwegingen werd geformuleerd, tot stand was gebracht 'onder zulk een zigtbare medewerking der goddelijke voorzienigheid, dat men zijne oogen zou moeten sluiten voor het licht, zoo men niet innerlijk bewogen erkende: de God der heerscharen heeft Nederland verlost' ! Met deze plechtige bededag werd beoogd de 'zuivere godsvrucht' op te wekken maar vooral 'den geest der godsdienstige vaderlandsliefde'. Zolang de strijd van de geallieerden tegen Napoleon voortduurde, werd op de eerste woensdag van elke maand voor het vaderland gebeden. Eind mei 1814 konden deze 'Maandelijksche Bede-stonden' worden opgeheven en op 20 juli 1814 volgde een algemene dank- vast- en bededag om 'den God onzer Vaderen' te eren voor de herstelde rust in Europa en de (Eerste) Vrede van Parijs ${ }^{31}$.

Op de hernieuwde instelling van de algemene dank- vast- en bededagen volgde een dag later het verzoek aan de verschillende bestuurslagen toe te zien op het in ere houden van de zondagen en christelijke feestdagen. De provisionele besturen van 'sGravenhage en Amsterdam maanden al eerder tot eerbiediging van de zondagsrust.

\footnotetext{
27 Knuttel-Catalogus, no. 23793.

28 Staatsblad, 26 november 1813.

29 Th. de Vries, Rutger Jan Schimmelpenninck (Nijmegen, 1979) 210.

30 Huisman, Neêrlands Israël, 92-93; A. Kuyper, Ons program (Hilversum-Pretoria, 1907) 305.

31 De tekst van het besluit betreffende de algemene dank- vast- en bededagen werd behalve in het Staatsblad ook gepubliceerd in de Staatscourant, 1 januari 1814 en de 's-Gravenhaagsche Courant, 3 januari 1814. Zie verder: Staatsblad (bijvoegsel) 20 mei en 22 juni 1814 en Staatscourant, 21 juni 1815.
} 


\section{A. I. W I E R D S M A}

Feestelijkheden, winkel- en straatverkoop dienden op zondag te worden gestaakt in navolging 'onzer brave voorvaderen die door deugd en Godsdienst de bloei en wei vaart van het dierbaar Vaderland onder Gods zegen bevorderd hebben'. Op overtredingen stond een boete van 3 gulden en bij herhaling werd dat bedrag verdubbeld; de opbrengsten kwamen ten goede van de armenzorg. Als gevolg van deze lokale bemoeienis varieerden de bepalingen van stad tot stad. De Zondagswet van 1 maart 1815 zou hierin orde brengen. De preambule benadrukte de noodzakelijkheid

om, op het voetspoor onzer godsdienstige voorvaderen ... de pligtmatige viering van den dag des Heeren en andere dagen den openbaren christelijken godsdienst toegewijd, door eenparige en voor de geheele uitgestrektheid der Vereenigde Nederlanden algemeen werkende maatregelen te verzekeren ${ }^{32}$.

De wet had volgens J. Th. de Visser een protestants aanzien omdat alleen met de in de protestantse kerken erkende feestdagen gerekend werd ${ }^{33}$.

Tot slot: vele gemeenten kennen behalve restanten van de oude Zondagswet tot op de dag van vandaag nog het zogenaamde ambtsgebed. Maar in het begin van de negentiende eeuw werd dit oude gebruik ook op nationaal niveau hooggehouden. De grondwetscommissie van 1814 makkte gebruik van een gebedsformulier waarin de zegen over de belangrijke werkzaamheden van de dag werd afgesmeekt. Vervolgens werd in de kabinetsraad gesproken over 'het Publieke Gebed' als onderdeel van het programma van de opening van de Staten-Generaal 34. In het 'Reglement van orde voor de Vergadering van Hun Edel Mogendheden de Heeren Staten-Generaal der Vereenigde Nederlanden', vastgesteld op 3 mei 1814, werd in het tweede artikel bepaald dat bij aanvang van de vergadering door de griffier een gebedsformulier werd opgelezen. De tekst van het ambtsgebed sloot aan bij dat van de grondwetscommissie en luidde als volgt:

Aanbiddelijke God! die door Uwe oneindige wijsheid het heelal regeert en ons geroepen hebt tot het bevorderen van de onafhankelijkheid van dezen Staat, van de vrijheid en welvaart van deszelfs ingezetenen, wij bidden $U$ ons in dit gewigtige werk te willen sterken door Uwen geest en ons te vergunnen die wijsheid, dat beleid, die standvastigheid, onpartijdigheid en eensgezindheid, waardoor wij, met een gerust geweten op Uwe goedertierendheid vertrouwende, Uwen dierbaren zegen over ons werk afsmeken en om Uwen zoon J. C. wille verwachten mogen. Amen.

\section{VERANDERINGEN IN HET STAATSCEREMONIEEL}

$\mathrm{Na}$ het besluit tot vereniging van Nederland en België in één koninkrijk werd op 22 april 1815 een nieuwe commissie benoemd die een herziening van de grondwet zou

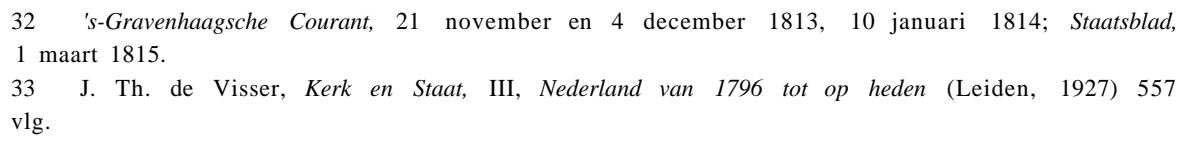


moeten ontwerpen met inachtneming van de artikelen opgesteld door het Weense Congres, waarin de uitgangspunten - onder andere de gelijkstelling van de kerkgenootschappen - van de vereniging van Noord en Zuid werden aangegeven. De verschillen binnen de grondwetscommissie werden al duidelijk in een van de eerste bijeenkomsten, waarin de zuidelijke leden werden geïnformeerd aangaande het gebed waarmee de commissie in 1814 steeds de beraadslagingen opende. Dat werd niet geaccepteerd: 'cette communion de prières pourrait ne pas s'accorder avec nos principes religieux' 35. Zo zou ook in het nieuwe parlementaire reglement van orde, waartoe dat van 1814 wel als uitgangspunt genomen werd, het ambtsgebed niet terugkeren. In het eindrapport van de grondwetscommissie werd het artikel betreffende de godsdienst van het staatshoofd uit de constitutie geschrapt. En in het officiële spraakgebruik maakte de 'God van Nederland' en de 'God Onzer Vaderen' plaats voor de veralgemeende 'God Almagtig', de 'Voorzienigheid', het 'Opperwezen' en de ' Almagtige Opperbestuurder der volken'.

$\mathrm{Na} 1820$ zouden bovendien de algemene dank- vast- en bededagen niet meer jaarlijks worden uitgeschreven. In antwoord op een petitie van de Hervormde Synode waarin voor handhaving van deze goede traditie werd geijverd, verklaarde baron Van Pallandt van Keppel, directeur-generaal voor de zaken van de hervormde eredienst, dat de overheid zich in deze terughoudend moest opstellen. Deze instelling was 'geheel in den geest der Protestanten, en daarom door oude herinneringen evenzo geschat bij hen, als weinig bemind bij de Roomsch-Catholijken, en zelfs in de zuidelijke gewesten aan dezelve geheel vreemd' 36 .

Ook in het inhuldigingsceremonieel werden op aandringen van de zuidelijke leden van de grondwetscommissie wijzigingen aangebracht. De plechtigheid zou niet per se in Amsterdam als hoofdstad maar afwisselend in een stad in het Noorden en in het Zuiden moeten worden voltrokken. De constitutie zou bij die gelegenheid moeten worden voorgelezen ter herinnering aan de hoofdbeginselen van het staatsrecht en het 'maakt dat de zaak niet zo spoedig afloope'. Verder zou de inhuldiging volgens oude, Bourgondische gewoonten in het openbaar en in de openlucht, 'publiek sub Dio', moeten plaatsvinden. Waarop Van Maanen, onder Willem I de belangrijkste minister maar als oudrevolutionair en beslist geen bewonderaar van het Belgische weinig enthousiast over een werkelijk koninklijk ceremonieel, spottend vroeg of het soms ook de bedoeling was dat het staatshoofd op een schild zou worden rondgedragen. Op voorstel van Van Hogendorp, die andermaal als voorzitter optrad, werd een subcommissie ingesteld voor de redactie van het inhuldigingsartikel 'met inachtneming der aangenomen veranderingen omtrent het beëedigen en inhuldigen in het openbaar en onder den blooten hemel, en verdere bepaling van de plaats waar deze plechtigheid geschieden moet'. In de grondwet van 1815 kregen deze wijzigingen hun beslag in 'Afdeeling V' van het eerste hoofdstuk onder het opschrift 'Van de inhuldiging des Konings' ${ }^{37}$.

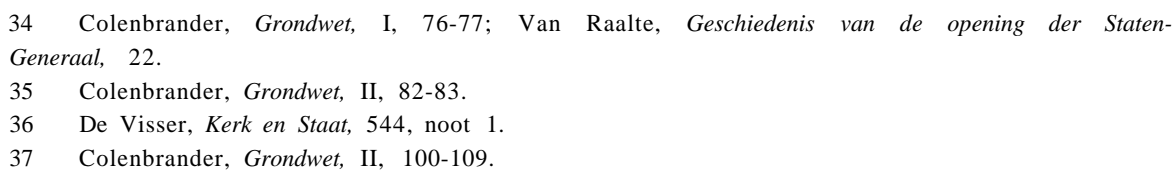


Dienovereenkomstig werd Willem I in 1815 als eerste koning beëdigd en ingehuldigd pp de koningsplaats te Brussel. De plechtigheid werd geheel op de gewijzigde verhoudingen afgestemd. De vorst sprak in zijn rede van een hereniging van beide rijksdelen die in de opstand tegen de Spaanse overheersing uiteen waren gedreven. Niet langer gold de Republiek als voorloper en voorbeeld in de ontstaansmythe van de nieuwe natie. Een ander opmerkelijk feit was de credenstafel, een dientafel waarop gewoonlijk de benodigdheden voor de mis werden gereedgelegd, maar nu de regalia - sinds de kerstening van het Romeinse Rijk voorzien van een kruis - werden uitgestald. Het programma vervolgde met een ontvangst in de Brusselse kathedraal 38.

In de Sint Goedele werd een plechtig Te Deum gezongen nadat de koning was ontvangen en toegesproken door de plebaan. Deze nam stelling tegen de kritiek van de Belgische clerus aangevoerd door de conservatieve M. de Broglie, bisschop van Gent. De campagne van De Broglie cum suis was aanvankelijk succesvol: het grondwetsontwerp werd door een meerderheid van de Belgische notabelen afgewezen. Het tegendeel kon echter worden beweerd na de 'arithmétique hollandaise'. De thuisblijvers en een deel van de tegenstemmers, namelijk die gebaseerd op het hoofdstuk van de godsdienst, werden bij de voorstemmers geteld op grond van de overweging dat gelijkstelling van de kerkgenootschappen als een van de uitgangspunten van de vereniging van Noord en Zuid opgesteld door het Weense Congres niet ter beoordeling van de notabelen stond ${ }^{39}$.

De toespraak van de plebaan stond lijnrecht tegenover de kritiek van de Gentse bisschop. De gelijkberechtiging van de verschillende kerkgenootschappen kon geen bedreiging zijn voor de positie van de katholieke kerk in België. Het staatshoofd zou zowel de protestantse als de katholieke leer beschermen "t welk ook den meest angstvalligen roomsch-katholieken moest gerust stellen, te meer nog daar deze bescherming nimmer geweigerd kan worden, om dat zij ons door de Grondwet zelve gewaarborgd wordt'. De kerkleer gebood bovendien onderwerping en gehoorzaamheid aan de koning die op de dag van de beëdiging en inhuldiging 'in de daad het beeld der goddelijkheid op aarde wordt' 40.

Enkele dagen na de inhuldiging verscheen in de Staatscourant het volgende bericht:

Brussel, 24 september. De Protestantsche gemeente vierde, heden morgen, op ene godsdienstige wijze, het feest der inhuldiging onzes geliefde Monarchs. De Wel. Eerw. Heer H. Pauw, Predikant bij de Nederduitsche Hervormde Gemeente te Brielle, daartoe van wege den koning uitgenodigd, hield in de Nederduitsche taal eene plegtige leerrede in de kerk der Protestanten. HH. MM. de koning en koningin, de Vorstinnen Douairières van Oranje en Brunswijk, de kroonprins van Oranje en deszelfs Broeder

\footnotetext{
38 Een programmaboekje is te vinden in de pamflettenverzameling van de Koninklijke Bibliotheek, Knuttel-Catalogus, no. 24138.

39 Vergelijk E. H. Kossmann, De lage landen 1780-1940 (Amsterdam, 1979) 93.

40 Opregte Dingsdagsche Haarlemsche Courant, 26 september 1815, facsimile in: Couvée en Pikkemaat, 1813-1815, 163.
} 
woonden dezen eeredienst bij, gelijk ook de Ministers en Staatsraden, de leden der beide Kamers en vele aanzienlijken ...

$\mathrm{Na}$ de katholieke eredienst woonde het qua godsdienst gemengde gezelschap op verzoek van de koning buiten het officiële programma om deze tweede kerkdienst bij. Het typeert de godsdienstpolitiek van Willem I, volgens J. A. Bornewasser samengevat in 'het credo ... geen reden van twist'. De godsdienstpolitiek werd stilzwijgend gebaseerd op de overigens weinig realistische verwachting van een versmelting van de geloofsovertuigingen. Willem I voorzag een Europees interconfessionalisme met de paus als hoofd van het christendom en de vorsten als hoofden van de nationale pluriforme kerken. De staat verwachtte van alle denominaties de zorg voor het christendom, de handhaving van de christelijke zeden, het bewaren van orde en eendracht, en het bevorderen van liefde voor koning en vaderland ${ }^{41}$.

\section{SCHEIDING VAN KERK EN STAAT}

Nadat in 1830 de unificatie-politiek van koning Willem I in de Belgische Opstand was geëindigd, groeide rond de noodzakelijk geworden grondwetswijziging in 1839 en de troonswisseling een jaar daarna het liberale protest, gesteund door de katholieken, tegen de besluitenregering en tegen de vermenging van godsdienst en politiek. Het Koninklijk Besluit dat eind december 1839 aan de voorstellen tot grondwetswijziging voorafging, sprak van een herziening volgens milde beginselen ter bevordering van het geluk van het volk 'door de beschikking der Goddelijke Voorzienigheid aan Onze zorgen toevertrouwd'. Tegen die formulering werd bezwaar gemaakt, omdat het de suggestie in zich zou hebben dat de soevereiniteit was gebaseerd op goddelijk recht. Het voorstel van enkele conservatieven om opnieuw de godsdienst van het staatshoofd in de grondwet vast te leggen, werd fel bestreden. Een enkeling weigerde zelfs aan verdere beraadslagingen deel te nemen. Het oude artikel, dat ook door G. Groen van Prinsterer in zijn brochure 'Bijdrage tot herziening der Grondwet in Nederlandsche zin' van 1840 was verdedigd, werd door liberalen en katholieken als onrechtvaardig, onstaatkundig en onverdraagzaam bestempeld. Uiteindelijk oordeelde een meerderheid in de Dubbele Kamer van 1840, waaronder toch ook Groen van Prinsterer, het niet raadzaam de bepaling in de nieuwe grondwet op te nemen omdat 'de tijden zodanig veranderd waren' ${ }^{\prime 2}$. De liberale kritiek ging echter veel verder. Bij de verdediging van het liberale voorstel tot grondwetswijziging in

41 Staatscourant, 26 september 1815; vergelijk Boogman, 'Nederlandse natie-besef, 77; J. A. Bornewasser, "Het credo ... geen reden van twist'. Ter verklaring van een koninklijk falen (1826-1829)', Archief voor de geschiedenis van de katholieke kerk in Nederland, XIX (1977) 234-287 en idem, 'Het koninkrijk der Nederlanden 1815-1830', in: Algemene Geschiedenis der Nederlanden, XI (1983) 257.

42 Handelingen Tweede Kamer 1839-1840, bijlage 389 vlg., 410-412, 427-428; I. A. Diepenhorst, Historisch-critische bijdrage tot de leer van den christelijken staat (Amsterdam, 1943) 36-37. 
1845, het voorstel van de Negenmannen, dat volgens de conservatieven niet met de oude Nederlandse beginselen overeenstemde, sprak J. R. Thorbecke over de 'Nederlandsche zin' als 'den vleijenden waan eener natie van het Oude Testament, dat er voor haar en haar bestuur een afzonderlijke God in de wereld was'. Thorbecke hoopte op het ontstaan van een Nederlands natiebesef met de 'godsdienst boven geloofsverdeeldheid' als gemeenschappelijk fundament van de moderne samenleving 43.

Rond de inhuldiging van koning Willem II in 1840 werden de politieke tegenstellingen in de dagbladen nog eens duidelijk verwoord. Het regeringsgezinde Algemeen Handelsblad zag in de beëdiging in de Nieuwe Kerk een plechtige bevestiging van de band tussen vorst en volk. De 'heiligheid van den Eed' onderstreepte de goede voornemens van het staatshoofd, de nabijheid van de stoffelijke resten 'van de De Ruiters en Van Galens, der Vondels, Verhulsten en Van Speyken, bij wier rustplaatsen die Eed is gesproken, geeft daaraan eene verhoogde betekenis, verbindt Vorst of onderdaan nauwer aan al wat Nederlandsch heet'. De oppositie was van deze 'gezwollen berichten', aldus het oordeel van J. de Bosch Kemper, niet gediend. De liberale Arnhemsche Courant beschouwde de feestelijkheden slechts als een afleiding van verdere grondwetswijzigingen. En het liberaal-katholieke dagblad NoordBrabander hoopte dat de eed niet zou zijn afgelegd op 'een laffe Grondwet..., maar bezworen in het harte en voor het oog van God' 44.

Ruim drieduizend toeschouwers volgens de Amsterdamsche Courant en meer dan vierduizend volgens de schatting van het Algemeen Handelsblad waren bij de inhuldigingsplechtigheid in de Nieuwe Kerk aanwezig. Uitgebreid beschreven de dagbladen de nieuw vervaardigde regalia en het met Nederlandse en Oranje vlaggen versierde kerkinterieur. In deze 'Feestzaal' hield ds. J. L. Wolterbeek als 'de oudste Predikant te Amsterdam', zoals in het inhuldigingsprogramma was vermeld, een korte toespraak gevolgd door een slotgebed en het laatste vers van Psalm 72: 'Zijn naam moet eeuwig eer ontvangen! Men loov' Hem vroeg en spaé'! De predikant verwees niet naar het drievoudig snoer van God, Nederland en Oranje, maar gebruikte eenzelfde godsbegrip als de oude koning Willem I in de verklaring bij zijn troonsafstand, de 'Almagtige Opperbestuurder der volken'. In plaats van Gods ingrijpen in de geschiedenis van Nederland volgens ds. Haack in 1814, was het nu Zijn woord waarop men moest vertrouwen. De bijbel, 'dat Wetboek der opperste Wijsheid', leerde niet alleen het einddoel van de ontwikkeling van de staat: de tijd 'dat de Staats-Maximen der wereldrijken geheel harmonieus met die van het Godsrijk zijn zullen', maar tevens de beginselen voor alle benodigde hervormingen. In de internationale oriëntatie, Gods onderwijzing van de enkele mens maar ook van de gehele mensheid geplaatst in een ontwikkelingsperspectief en de Schrift als bron van de (hier staatsrechtelijke) dogmatiek zijn elementen van de Groninger theologie te herkennen ${ }^{45}$.

43 Handelingen Tweede Kamer 1844-1845, 489; vergelijk W. Banning, Hedendaagse sociale bewegingen (Arnhem, 1954) 35.

44 Algemeen Handelsblad, 24 november 1840, Arnhemsche Courant, 6 oktober 1840, NoordBrabander, 3 december en 31 december 1840; J. de Bosch Kemper, Geschiedenis van Nederland na 1830, IV (1875) 7-8. 
Kort na de inhuldigingsfeesten schreef de Noord-Brabander dat in het woord 'plegtiglijk' van het inhuldigingsartikel van de grondwet niet besloten lag dat de regalia of 'zinnebeelden des Grondwettigen Koningschap' in staatsie moesten worden meegevoerd, noch dat in een protestantse kerk, door een protestantse predikant een toespraak en gebed worden uitgesproken en 'Gereformeerde Psalmen' in aanwezigheid van ook katholieke volksvertegenwoordigers worden gezongen. Dat de katholieke kamerleden hadden meegedaan met het psalm-gezang, zoals uit de Staatscourant kon worden opgemaakt, ging de Noord-Brabander echt te ver. 'Men zou zich hier te lande zelfs tot aan de Besnijdenis toe wagen als het Handelsblad maar geliefde te verklaren dat ook deze een zinnebeeld was van 't Constitutionele Koningschap'. De oude spreuk 'Eendragt maakt Macht' was volgens de liberaal-katholieken geen recht gedaan door de vermenging van kerk en staat in het protestantse karakter van de inhuldigingsplechtigheid 46

Met de herziening van de grondwet in 1840 en de liberale grondwetswijziging van 1848 verdwenen de Belgische bijdragen aan het inhuldigingsceremonieel. In 1848 werd bovendien de geloofsvrijheid ook in het grondwettelijk voorgeschreven eedformulier van het staatshoofd gerespecteerd. Zoals voor andere officiële functies al gebruikelijk was, kreeg ook de koning of koningin de keuze tussen 'Zo waarlijk helpe mij God Almachtig' en 'Dat beloof ik'. Aan de kritiek van 1840 op de protestantse godsdienstoefening als onderdeel van het inhuldigingsprogramma werd gehoor gegeven. Wanneer in 1849 Willem III zijn kort daarvoor overleden vader opvolgt, wordt de beëdiging en inhuldiging op een gewone zondag en in een ander kerkgebouw godsdienstig gevierd. In het inhuldigingsprogramma werd dit niet meer in een afzonderlijk artikel opgenomen, maar als een mededeling voorafgaand aan algemene bepalingen alsof het hier een persoonlijke aangelegenheid van de nieuwe koning betrof. Door het laatste liberale ministerie werd in 1898 ter gelegenheid van de beëdiging en inhuldiging van koningin Wilhelmina de tot dan toe bij bijzondere gebeurtenissen rond het Huis van Oranje gebruikelijke bededag niet meer uitgeschreven. Bovendien werd in het nationale programma geen kerkdienst opgenomen. Een godsdienstige viering was toen onderdeel van het programma van de Haagse feestcommissie ${ }^{47}$. Met andere woorden, de staat richtte zich ook in het ceremonieel meer naar het neutraliteitsbeginsel. De godsdienst werd een zaak van de private sfeer, in casu van het staatshoofd, de kerken en het particulier initiatief.

\section{GEEN ETAT ATHEE}

Rond de eeuwwisseling verscheen het beginsel van de scheiding van kerk en staat in de aktie-programma's van de liberale en socialistische partijen. Daarbij ging het om

\footnotetext{
45 Knuttel-Catalogus, no. 21841; A. J. Rasker, De Nederlandse Hervormde Kerk vanaf 1795 (Kampen, 1981) $47 \mathrm{vlg}$.

46 Noord-Brabander, 26 november, 3 december en 31 december 1840.

47 De Visser, Kerk en Staal, 553; Staatscourant, 9 augustus 1898; NRC, 10 september 1898.
} 
meer dan de beëindiging van de financiële betrekkingen. De zondagswet zou moeten worden ingetrokken of tenminste herzien en de vrije keuze tussen eed en belofte zou de eedsplicht moeten vervangen die in de rechtszaal nog werd gehandhaafd. Maar een kamermeerderheid hield radicale wijzigingen tegen. Voor (gematigd) liberalen waren dit niet de belangrijkste strijdpunten, terwijl de antithese de confessionelen juist voor deze 'questies' zeer gevoelig maakte. In Ons Program verdedigde Kuyper de zondagsheiliging tegenover de geseculariseerde zondagsrust en de eed werd het 'cement van het staatsbestel' genoemd ${ }^{48}$. Ook het ambtsgebed zôu moeten worden gehandhaafd, in elk geval op gemeentelijk niveau. Nadat de Amsterdamse gemeenteraad in 1919 op voorstel van een van de communistische raadsleden besloot tot afschaffing van het ambtsgebed, werd het prompt in vele andere gemeenten, ook waar een katholieke meerderheid bestond, in het reglement van orde opgenomen; na de tweede wereldoorlog zorgde de reactie op de doorbraakgedachte voor een nieuwe piek in de invoering van het ambtsgebed ${ }^{49}$.

Met de toenemende politieke invloed van de confessionele partijen, na de invoering van het algemeen mannenkiesrecht en de evenredige vertegenwoordiging in 1918 alleen nog beperkt door onderlinge meningsverschillen, werd het christelijk karakter van de Nederlandse samenleving weer meer benadrukt. In 1916 trad het extraparlementaire kabinet-Cort van der Linden, bestaande uit vrijzinnigen, ook ten aanzien van de eedskwestie op als een 'eerlijk makelaar' tussen rechts en links. Na verschillende wijzigingen in het regeringsvoorstel werd de 'eedsverplichting, zonder consciëntiedwang' door beide Kamers aanvaard. Nadrukkelijk werden eed en belofte niet gelijkgesteld. Op voorstel van de CHU diende ter vervanging van de eed door de belofte een schriftelijke verklaring te worden afgegeven dat men onoverkomelijke bezwaren heeft tegen het afleggen van eden ook wanneer een wettelijk voorschrift de eed vordert. Volgens sommigen werden zo 'sacrementele eischen' gesteld aan de toelating tot de belofte ${ }^{50}$.

Enkele jaren later onder het coalitiekabinet-Ruys de Beerenbrouck, sprak de toenmalige minister van justitie J. Donner, als vanzelfsprekend over de talrijke voorbeelden van de erkenning van God in de openbare sfeer. Het regeringsvoorstel van 1932 tot het strafbaarstellen van smalende Godslastering, een reactie op enkele aanstootgevende publikaties in het communistische dagblad De Tribune, bracht volgens de minister nog eens tot uitdrukking dat de Nederlandse staat 'ook bij de ruimste erkenning van godsdienstvrijheid niet is een Etat athée ${ }^{151}$.

Als een van de voorbeelden noemde Donner het koningschap 'bij de gratie Gods' en wellicht werd daarbij ook gedacht aan de inhuïdigingsplechtigheid in 1898, de troonsbestijging van koningin Wilhelmina. In het commentaar van de buitenlandse correspondenten op de inhuldigingsfeesten werden toen de religieuze kanten van het

48 Kuyper, Ons program, $99 \mathrm{vlg}$.

49 A. J. Kret, 'Kroniek van het ambtsgebed', Bestuurs-forum (1980) 122-128.

50 J. van Baars, 'Over de rechtshistorie van het eedsvraagstuk in Nederland sinds 1910', Nederlands Juristenblad, (1969) xvi 357-366 en xvii, 381-391; de uitdrukking 'sacramentele eischen' is van mr. Tak, zie Nederlandse Jurisprudentie 1919, no. 1105.

51 Memorie van Toelichting, Bijlagen Handelingen Tweede Kamer 1930-1931, 348, 1-3. 
koningschap duidelijk. Opgemerkt werd dat in tegenstelling tot de Engelse kroning in Nederland uit eerbied voor ieders gewetensvrijheid de plechtigheid geen kerkdienst was, maar het volk rond de dag van de troonswisseling wel massaal ter kerke ging. In al die manifestaties, aldus een van de verslaggevers, heeft men 'het godsdienstig karakter van dit volk kunnen waarnemen'. De vergadering van de Staten-Generaal in de Nieuwe Kerk, het getuigenis en de bede in de inhuldigingsrede, de eedaflegging, de keuze van de inhuldigingszetel - in 1849, 1898 en 1948 met een in goud geborduurd Alziend Oog — , de credenstafel voor de regalia en de grondwet, de kerkelijke liederen, etc, al deze gebruiken en symbolen 'waren als een echo van het Wilhelmus en verhieven de gedachten telkens tot den Almachtige' 52.

Het inhuldigingsceremonieel was in de jaren 1898, 1948 en 1980 vrijwel identiek. Toch stelde J. Romein in zijn De lage landen bij de zee niet ten onrechte dat zeker na het eind van de negentiende eeuw het koningschap zijn sacraal karakter heeft verloren. Zo werd de Nieuwe Kerk van een protestants kerkgebouw in de ogen van de katholieken van het midden van de vorige eeuw omgevormd tot een nationaal monument, dat in 1948 kort voor de inhuldiging van koningin Juliana ruimte gaf aan de oprichtingsbijeenkomst van de Wereldraad van Kerken en bij de laatste restauratie enkele maanden voor de troonsopvolging door koningin Beatrix in 1980 werd omgedoopt in een 'praathuis der democratie ${ }^{153}$. Na 1898 stonden verschillende interpretaties van het koningschap 'bij de gratie Gods' naast elkaar; een inflatie van de symboliek. De Gereformeerde Synode schreef nog in 1948 over het Huis van Oranje als Gods instrument: 'Vijftig jaren heeft God de Nederlanden geregeerd door de hand van onze Koningin Wilhelmina'. In het herderlijk schrijven van de bisschoppen werd het koningschap 'bij de gratie Gods' eenvoudig tot Gods ordening gerekend. De Tijd zag het vijftigjarig bewind van de oude koningin als een periode van 'een verheugend naar elkaar toegroeien', zowel politiek als godsdienstig, mede gestimuleerd door 'die voorbeeldig Christelijke praktijk welke het leven is van Koningin Wilhelmina ... Een heldin is $\mathrm{Zij}$ in nationale zin, een heldin is $\mathrm{Zij}$ in Christelijke zin'. Ds. Van Beem, voorzitter van de kerkeraad der Nederlands Hervormde Gemeente, sprak op een andere toon in een dankdienst in de Oude Kerk te Amsterdam ter gelegenheid van de verjaardag en de troonsafstand van koningin Wilhelmina. Voor de regering van de scheidende vorstin was de gratie Gods 'deze, dat Hij haar sterkte om de zware taak te volbrengen'. De NRC prees de nieuwe koningin om haar spontaniteit, originaliteit en grote eenvoud, waarmee zij paste in de moderne tijd van 'gewone' vorsten die zich niet 'bij Gods genade' afzonderen maar een normaal open leven leiden ${ }^{54}$.

Langzaam zouden de tegenstellingen tussen geloof en ongeloof en tussen christendom en humanisme verdwijnen. In 1965 werden in de regeringsverklaring van het kabinet-Cals, de tussentijdse coalitie van KVP, ARP en PvdA, beide inspiratiebronnen als fundamenten van het beleid genoemd. In 1967 behaalden de confes-

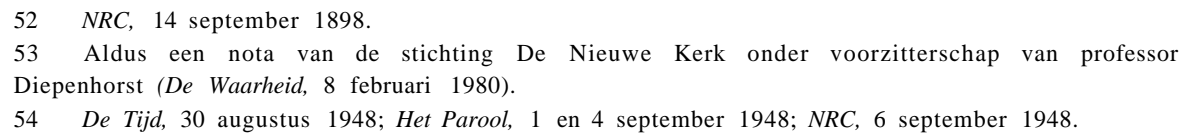


sionele partijen bovendien voor het eerst sinds 1918 minder dan de helft van het aantal kamerzetels. De gewijzigde politieke verhoudingen werden ook omgezet in wetswijzigingen. De nieuwe Zondagswet richt zich vooral op de zondagsrust en de nieuwe eedswet laat de keuze tussen eed of belofte geheel vrij. De grondwetswijziging van 1983 stelde godsdienst en levensovertuiging gelijk, schrapte het oude hoofdstuk 'van de godsdienst' en voegde de godsdienstvrijheid bij de klassieke grondrechten. Maar verschillende gebruiken in het grensgebied van godsdienst en politiek werden ondanks alle kritiek gehandhaafd. Het staatshoofd regeert nog altijd 'bij de gratie Gods' en ook koningin Beatrix legde in 1980 de eed af. Veel gemeenten kennen behalve restanten van de oude zondagswet ook nog het ambtsgebed, al is dat ceremonieel op zijn retour door gemeentelijke herindeling en linkse colleges. In de jaren 1973 tot 1976 werd door toedoen van de sociaaldemocraten de bede in de troonrede afgeschaft, maar zonder blijvend resultaat. Een tegenactie onder leiding van enkele hervormde predikanten en de christelijke Oranjeverenigingen had weliswaar niet onmiddellijk succes, maar enkele jaren later werd door het kabinet-Lubbers-Van Aardenne de bede bijna onopgemerkt weer ingevoerd. $\mathrm{Na}$ de ophef over de troonrede zonder bede werd door enkele PvdA-kamerleden door middel van kamervragen een voorzichtige poging gedaan om het sinds 1818 gebruikelijke randschrift 'God zij met ons' ter discussie te stellen. Maar de minister zag daar de noodzaak niet van in. Blijkens een recente opiniepeiling zijn er in de Nederlandse samenleving nog altijd ruime meerderheden vóór handhaving van de bede en het muntrandschrift ${ }^{55}$. Is dit nostalgie of staat zoals in de Verenigde Staten van Amerika tegenover de individuele godsdienstigheid een vage, gegeneraliseerde publieke godsdienst? Die vraag laat zich niet zo gemakkelijk beantwoorden, maar het voortbestaan van de vermenging van godsdienst en politiek in het staatsceremonieel lijkt voorlopig nog verzekerd.

55 De uitslagen van een enquête van de Vara (M. de Hond) werden bekend gemaakt in het radioprogramma 'In de rode haan', 19 april 1986. 


\section{H. VAN DER WEE}

\section{INLEIDING}

De Belgische economie, open en kwetsbaar, werd door de wereldcrisis van de jaren 1975-1985 zwaar getroffen. De duurdere energieprijzen van het midden en einde van de jaren zeventig, en de vermindering van de wereldvraag die erop volgde, leidden tot een verslechtering van de handelsbalans, tot een verlies van afzetmarkten, tot een sterkere importpenetratie.

De overheid reageerde aanvankelijk met een Keynesiaanse conjunctuurpolitiek. De overheidsuitgaven stegen aanzienlijk en neutraliseerden het negatieve effect van de déficitaire handelsbalans. De welvaartsillusie werd in stand gehouden door een expansieve overheid.

Het gevoerde beleid sorteerde drie neveneffecten. In de eerste plaats bleef de overlegeconomie overeind. In feite versterkte ze zich nog verder: de reële lonen bleven stijgen, de sociale zekerheid en de openbare nutsvoorzieningen breidden zich verder uit, talrijke ondernemingen werden gesubsidieerd, een deel van het overtollige arbeidsaanbod werd door de overheid opgeslorpt. Niettegenstaande deze opslorpingspolitiek bleef de werkloosheid onrustwekkend stijgen, en dit was het tweede belangrijke neveneffect. De hoge loonkosten in een wereldomgeving die omwille van de crisis steeds competitiever werd, bracht een aantal ondernemers ertoe hun verlieslatende bedrijven te sluiten. Anderen schorsten hun uitbreidingsinvesteringen en vervingen ze door diepteinvesteringen gericht op arbeidsbesparing.

Het derde neveneffect betrof het toenemend begrotingstekort, dat op de particuliere investeringen in België een nefaste invloed begon uit te oefenen en geleidelijk een klimaat creëerde van onrust over de toekomst van het land. Het groeiend onbehagen over de ontwikkeling van de Belgische economie, de tweede olieschok van 19781979 en de dollarschok, die kort daarop volgde, brachten een beslissende kentering in het overheidsbeleid. De muntherschikking van februari 1982, gekoppeld aan een strakke monetaire politiek, aan een algemene loonmatiging en aan een selectieve prijsstop, beoogde een verbetering van de concurrentiepositie van het Belgisch bedrijfsleven tegenover het buitenland. Terzelfder tijd werden extra maatregelen in het vooruitzicht gesteld om de publieke financiën te saneren en om de werkgelegenheid te verbeteren.

De Keynesiaans-geïnspireerde conjunctuurpolitiek van de jaren zeventig werd

\footnotetext{
* Tekst van een voordracht gehouden op de jaarvergadering van het NHG op 17 oktober 1986. Voor een meer uitvoerige bespreking van het behandelde probleem, zie: H. van der Wee, 'De Belgische economie in de maalstroom van een halve eeuw, 1925-1975', in: Gaston Eyskens, 80: Hulde colloquium. Brussel, Paleis voor Congressen, 22 juni 1985 (Tielt: Lannoo, 1985) 57118. Een bijzonder woord van dank aan drs. E. Buyst en S. Peeters, voor hun hulp bij het voorbereiden van deze tekst.
} 